ISSN 0258-7122 (Print), 2408-8293 (Online)

Bangladesh J. Agril. Res. 44(4): 591-598, December 2019

\title{
REQUIREMENT OF DIFFERENT NUTRIENTS FOR YIELD MAXIMIZATION OF BT BRINJAL
}

\author{
M. A. K. MIAN ${ }^{1}$, A. A. BEGUM ${ }^{2}$ AND R. R. SAHA ${ }^{3}$
}

\begin{abstract}
The experiment was conducted at Agronomy field of Bangladesh Agricultural Research Institute, Gazipur during 2016-2017 and 2017-2018 to determine the nutrient requirement for yield maximization of Bt brinjal (var. BARI Bt Begun2 ). The treatments were $\mathrm{T}_{1}=\mathrm{STB}$ (soil test base) recommendation (120-36-90$15-2-1 \mathrm{~kg} / \mathrm{ha} \mathrm{N}-\mathrm{P}-\mathrm{K}-\mathrm{S}-\mathrm{Zn}-\mathrm{B}+3 \mathrm{t} / \mathrm{ha}$ poultry manure), $\mathrm{T}_{2}=\mathrm{T}_{1}+25 \%$ of N-P-KS-Zn-B (150-45-112-18-2.5-1.25 kg/ha N-P-K-S-Zn-B +3 t/ha poultry manure), $\mathrm{T}_{3}=\mathrm{T}_{1}+50 \%$ of N-P-K-S-Zn-B (180-54-135-22-3-1.50 kg/ha N-P-K-S-Zn-B +3 $\mathrm{t} /$ ha poultry manure), $\mathrm{T}_{4}=\mathrm{T}_{1}+25 \%$ of N-P-K-S-Zn-B $+3 \mathrm{t} /$ ha poultry manure (150-45-112-18-2.5-1.25 kg/ha N-P-K-S-Zn-B+6 t/ha poultry manure), $\mathrm{T}_{5}=\mathrm{T}_{1}+$ $3 \mathrm{t} /$ ha poultry manure $(120-36-90-15-2-1 \mathrm{~kg} / \mathrm{ha} \mathrm{N}-\mathrm{P}-\mathrm{K}-\mathrm{S}-\mathrm{Zn}-\mathrm{B}+6 \mathrm{t} / \mathrm{ha}$ poultry manure). Nutrient uptake, yield components and yield of $\mathrm{Bt}$ brinjal varied significantly due to variation of nutrients in the tested years. The highest plant height $(98-116 \mathrm{~cm})$, canopy coverage $\left(1.21-1.26 \mathrm{~m}^{2} / \mathrm{plant}\right)$, number of fruits/plant (57.69-59.23) and individual fruit weight (83-86 g) were obtained from $180-54-135-22-3-1.50 \mathrm{~kg} / \mathrm{ha}$ N-P-K-S-Zn-B $+3 \mathrm{t} /$ ha poultry manure $\left(\mathrm{T}_{3}\right.$ treatment where days to flowering showed the lowest values (109-110 days). The highest pooled yield (58.46 t/ha) of Bt brinjal was observed from the treatment 180-54-135-22-3-1.50 kg/ha N-P-K-S-Zn-B +3 t/ha poultry manure $\left(\mathrm{T}_{3}\right)$ and the lowest (23.39 t/ha) from 120-36-90-15-2-1 kg/ha N-P-K-S$\mathrm{Zn}-\mathrm{B}+3 \mathrm{t} / \mathrm{ha}$ poultry manure) $\left(\mathrm{T}_{1}\right)$. The highest nutrient uptake (214-43-208-600.38-0.213-49 kg/ha N-P-K-S-B-Ca) was also observed from the same treatment $\left(\mathrm{T}_{3}\right)$. Fruit yield showed a strong $(\mathrm{r}=0.97)$ linear relationship with applied nutrients. Effect of nutrient application on fruit yield of Bt brinjal was estimated about $86 \%$. The highest gross return (Tk. 587900/ha), gross margin (Tk. 417660/ha) and benefit cost ratio (3.45) were obtained by applying 180-54-13522-3-1.50 kg/ha N-P-K-S-Zn-B+3 t/ha poultry manure. Results revealed that application of 180-54-135-22-3-1.50 kg/ha N-P-K-S-Zn-B along with $3 \mathrm{t} / \mathrm{ha}$ poultry manure would be economically optimum for achieving higher yield of Bt brinjal grown under Grey Terrace soil (Aeric Albaquept) of Gazipur.
\end{abstract}

Keyword: Nutrient requirement, nutrient uptake, yield and Bt brinjal

\section{Introduction}

Brinjal (Solanum melongena) is the third most important vegetable in terms of both yield and production area in Bangladesh. Recently Bangladesh Agricultural

${ }^{1}$ Principal Scientific Officer, ${ }^{2}$ Senior Scientific Officer, ${ }^{3}$ Chief Scientific Officer, Agronomy Division, Bangladesh Agricultural Research Institute (BARI), Gazipur-1701, Bangladesh. 
Research Institute has developed four Bt brinjal varieties. It has high potentiality to boost up the yield and brinjal production of the country. Bt brinjal needs additional fertilizer than the recommended dose for proper growth and yield (Mian, 2017). Optimum nutrient dose exerts proper growth and development of crop plant contributing to better yield components and yield (Morgan and Connolly, 2013). Nutrient involves in many important metabolic processes in the plant system and influences the growth and development of crop plant. Recommended fertilizer dose for non Bt brinjal is generally used in Bt brinjal because of no fertilizer recommendation for Bt brinjal yet in Bangladesh (FRG, 2018). Bt brinjal produced lower yield when recommended fertilizer dose for non Bt brinjal is used in Bt brinjal (BARI, 2017). Previous field experience and observation indicated that Bt brinjal has profused bearing than non Bt brinjal. Hence, higher fertilizer dose may require for full exploitation of yield potentiality of $\mathrm{Bt}$ brinjal. Most of the flowering buds of Bt Brinjal are active for fruiting. $\mathrm{Bt}$ gene is resistance to brinjal shoot and fruit borer of Bt brinjal. Probably Bt gene is also tolerance to fungal disease development on flowering buds of Bt brinjal. Consequently, more active flowering buds produce more fruits/plant and higher yield of Bt brinjal. Higher fruit yield of Bt brinjal may require high nutrient dose as compared to recommended nutrient dose for non Bt Brinjal because of high nutrient uptake by Bt Brinjal from the soil. There is a positive relationship between yield and nutrient uptake of a crop (Masni and Wasli, 2019). On the other hand, one of the major causes of low yield of brinjal might be due to low organic matter content as well as low nutrient status of soils those has been declined over time (Mian, 2008). Application of higher dose of nutrients than at present nutrient recommendation for non $\mathrm{Bt}$ brinjal may improve the yield of $\mathrm{Bt}$ brinjal. Moreover, optimum application of nutrient provides better agronomic and economic benefits to brinjal growers. Very little information is available regarding fertilizer management in Bt brinjal. As such, there is a need to recommend the fertilizer requirement for Bt brinjal. Therefore, the experiment was undertaken to find out economic fertilizer dose for achieving high yield of $\mathrm{Bt}$ brinjal.

\section{Materials and Methods}

The experiment was conducted at Agronomy field of Bangladesh Agricultural Research Institute, Gazipur during 2016-2017 and 2017-2018. The soil of the experimental field is clay loam under Chhiata series. Soil samples were collected from a depth of $0-20 \mathrm{~cm}$ prior to application of fertilizer in both the years. Results of soil analysis are presented in Table 1. Organic matter content and total $\mathrm{N}$ were very low. Exchangeable $\mathrm{K}$ and available $\mathrm{P}, \mathrm{S}, \mathrm{Zn}$ and $\mathrm{B}$ were found to be below the critical level. Five treatments consist of $T_{1}=120-36-90-15-2-1 \mathrm{~kg} / \mathrm{ha}$ of N-P-K-S-Zn-B+ 3 t/ha poultry manure based on STB (FRG, 2012), $\mathrm{T}_{2}=\mathrm{T}_{1}+$ $25 \%$ of N-P-K-S-Zn-B (150-45-112-18-2.5-1.25 kg/ha of N-P-K-S-Zn-B +3 t/ha poultry manure), $\mathrm{T}_{3}=\mathrm{T}_{1}+50 \%$ of N-P-K-S-Zn-B (180-54-135-22-3-1.50 kg/ha of N-P-K-S-Zn-B +3 t/ha poultry manure), $\mathrm{T}_{4}=\mathrm{T}_{1}+25 \%$ of N-P-K-S-Zn-B +3 $\mathrm{t} / \mathrm{ha}$ poultry manure $(150-45-112-18-2.5-1.25 \mathrm{~kg} / \mathrm{ha}$ of $\mathrm{N}-\mathrm{P}-\mathrm{K}-\mathrm{S}-\mathrm{Zn}-\mathrm{B}+6 \mathrm{t} / \mathrm{ha}$ 
poultry manure), $\mathrm{T}_{5}=\mathrm{T}_{1}+3 \mathrm{t} / \mathrm{ha}$ poultry manure (120-36-90-15-2-1 kg/ha of N-P$\mathrm{K}-\mathrm{S}-\mathrm{Zn}-\mathrm{B}+6 \mathrm{t} / \mathrm{ha}$ poultry manure). The experiment was conducted in a randomized complete block (RCB) design with three replications. Unit plot size was $6.4 \mathrm{~m} \times 5.4 \mathrm{~m}$. All of poultry manure, phosphorus, sulphur, zinc and boron fertilizers were applied at the time of final land preparation. Nitrogen and potassium fertilizers were applied in four equal splits at 20, 40, 60 and 80 DAT (days after transplanting) around the plant roots and mixed thoroughly with the soil. The brinjal var. BARI Bt Begun-2 was used as test crop. Thirty days old seedling was transplanted on 11 November 2016 and 16 November 2017 at a spacing of $90 \mathrm{~cm} \times 80 \mathrm{~cm}$. Intercultural operations such as weeding, mulching, irrigation etc. were done as per requirement. The crop was harvested from 8-12 February to 1-5 April in 2017 and 2018. Frequent rainfall $(66-107 \mathrm{~mm}$ in February to April) at later stage affected the crop (Fig.2) and drastically reduced fruit yield. Nutrient concentration in fruit and plant tissues of Bt brinjal was analyzed following the standard laboratory procedures. Nutrient uptake was computed on the basis of dry matter accumulation of Bt Brinjal and nutrient concentration in the tissues (both fruit and plant). Correlation of yield with nutrient uptake and nutrient uptake with applied nutrients were done. Functional relationship between total applied nutrient and fruit yield of Bt brinjal were established. Nutrient from poultry manure were calculated and considered in total applied nutrient (FRG, 2012). Data on yield and other associated characters were recorded. Canopy coverage was measured by meter-stick method (Armbust, 2009). Vertical projection area of the outer most perimeter of the natural spread of foliage of plants was measured. Soil surface coverage ( $D=$ diameter of coverage of the plant) was measured at four positions of spreading margin of the plant canopy (perimeter) perpendicular to the soil surface. Randomly selected 5 plant's canopy coverage $(\mathrm{D}=$ diameter $)$ was measured from each plot. Then mean value was calculated using the following formula. This measurement $\left(A=\pi r^{2}\right.$ where, $\mathrm{D}=2 \mathrm{r}$ ) was done at first harvesting time of fruits. Data on yield and other associated characters were recorded. Collected data was subjected to analysis of variance. Least significant difference (LSD) value was used for mean separation and treatments means were compared by LSD (0.05) (Gomez and Gomez, 1984). Cost benefit analysis was also evaluated.

Table 1. Chemical properties of the experimental soil (average of two years)

\begin{tabular}{l|c|c|c|c|c|c|c|c}
\hline \multicolumn{1}{|c|}{ Properties } & $\mathrm{pH}$ & $\mathrm{OM}(\%)$ & $\begin{array}{c}\text { Total } \\
\mathrm{N} \\
(\%)\end{array}$ & $\begin{array}{c}\text { Exchangeable } \\
\mathrm{K} \\
(\mathrm{meq} / 100 \mathrm{~g} \\
\mathrm{soil})\end{array}$ & $\begin{array}{c}\mathrm{P} \\
(\mathrm{ppm})\end{array}$ & $\begin{array}{c}\mathrm{S} \\
(\mathrm{ppm})\end{array}$ & $\begin{array}{c}\mathrm{Zn} \\
(\mathrm{ppm})\end{array}$ & $\begin{array}{c}\mathrm{B} \\
(\mathrm{ppm})\end{array}$ \\
\hline $\begin{array}{l}\text { Nutrient } \\
\text { Status }\end{array}$ & 6.25 & 1.73 & 0.079 & 0.16 & 8.09 & 9.88 & 0.47 & 0.18 \\
\hline Critical limit & - & $\mathrm{C}: \mathrm{N}=10: 1$ & 0.12 & 0.12 & 10 & 10 & 0.60 & 0.20 \\
\hline Interpretation & Acidic & $\mathrm{VL}$ & $\mathrm{VL}$ & $\mathrm{L}$ & $\mathrm{L}$ & $\mathrm{L}$ & $\mathrm{L}$ & $\mathrm{L}$ \\
\hline
\end{tabular}

$\mathrm{VL}=$ Very low, $\mathrm{L}=$ Low 


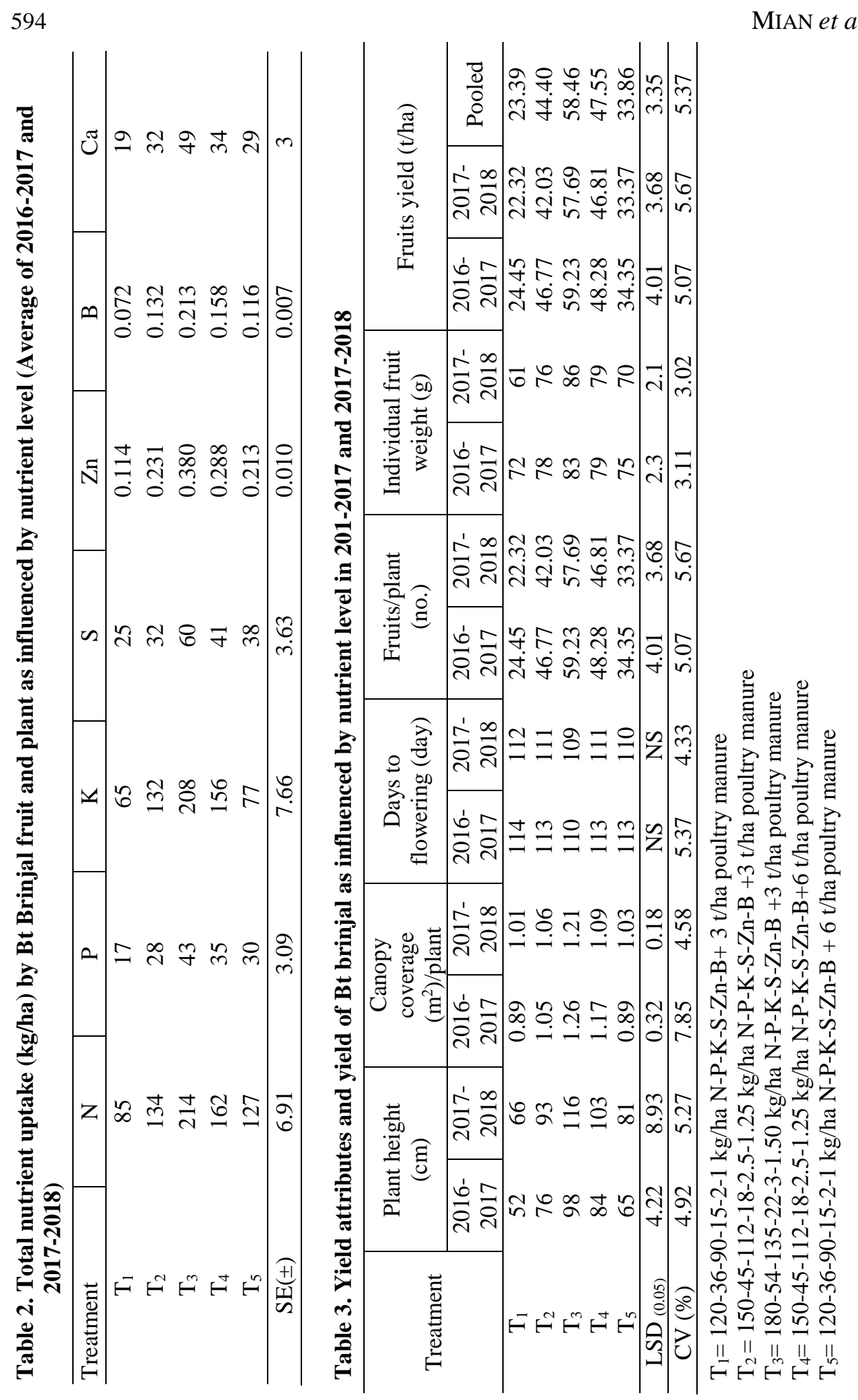




\section{Results and Discussion}

\section{Nutrient uptake:}

Uptake of N, P, K, S, Zn, B and Ca by whole plant (stem+leaves+fruit) of Bt brinjal differed among the treatments (Table 2). $\mathrm{N}$ uptake by both shoot and fruit varied from 85 to $214 \mathrm{~kg} / \mathrm{ha}$. The highest $\mathrm{N}$ uptake by whole plant occurred in the 180-54-135-22-3-1.5 kg/ha N-P-K-S-Zn-B + 3 t/ha poultry manure $\left(\mathrm{T}_{3}\right)$ treatment. Higher nutrient application into soil enhanced crop growth as well as total dry matter resulting the highest nutrient uptake from soil. Similar results were also reported by Ghosh et al. (2014). The uptake of $\mathrm{N}$ was the lowest in the treatment $120-36-90-15-2-1 \mathrm{~kg} / \mathrm{ha}$ N-P-K-S-Zn-B+ 3 t/ha poultry manure $\left(\mathrm{T}_{1}\right)$ possibly due to lower availability of $\mathrm{N}$ coupled with lower dry matter. $\mathrm{P}, \mathrm{K}, \mathrm{S}$, $\mathrm{Zn}, \mathrm{B}$ and Ca uptake by whole plant of Bt brinjal also followed a similar pattern to that obtained for $\mathrm{N}$ uptake (Table 2).

\section{Plant height and yield attributes:}

Plant height and canopy coverage/plant showed significant variation among the nutrient level in both the years (Table 3). Plant height was found maximum in $\mathrm{T}_{3}$ treatment followed by $\mathrm{T}_{4}$ treatment and the lowest from $\mathrm{T}_{1}$. Similar trend was also observed in the case of canopy coverage/plant. Higher nutrient level increased plant height and canopy coverage indicated better crop growth. Similar results were reported by Khanum et.al. (2017) in Bt Brinjal. Days to flowering did not differ significantly among the treatments in both the years. Days to flowering ranged from 109-114 days being the lowest value from $\mathrm{T}_{3}$ treatment (Table 3). The results indicated that higher nutrient level enhanced early flowering (Ahmad et al., 2011; Sajid and Amin, 2014). The highest number of fruits/plant was found in $\mathrm{T}_{3}$ treatment and it was significantly different from all other treatments. The lowest number of fruits/plant was obtained from $T_{1}$ treatment. The result indicated that higher nutrient level enhanced crop growth resulting higher fruits/plant. Similar results were reported by Sharma and Guru (2016) in brinjal. Individual fruit weight varied considerably and increased significantly in different treatments as compared to $T_{1}$. The highest fruit weight was recorded in $\mathrm{T}_{3}$ treatment and it was significantly superior to all other treatments in both the years. Treatment $T_{1}$ produced the lowest individual fruit weight.

\section{Fruit yield:}

Application of different nutrients (higher nutrients) increased fruit yield from 24.45 to 59.23 t/ha in 2016-2017 and 22.32 to 57.69 t/ha in 2017-2018 (Table 3). The highest fruit yields (59.23 t/ha in 2016-2017 and 57.69 t/ha in 2017-2018) were obtained from $\mathrm{T}_{3}$ treatment and it was significantly different from all other treatments. The result indicates that Bt brinjal produced higher fruit yield at higher nutrient level as it was required for exploitation of it's high yield 
potentiality. The results are in agreement with the findings of Anonymous (2017) and Mian (2017). The yield advantage was achieved through greater nutrient uptake by Bt brinjal resulting increased fruits/plant and individual fruit weight which eventually increased fruit yield of Bt brinjal. Recommended nutrient level for brinjal produced lower yield of Bt brinjal in both the years. Fruit yield was significantly correlated with applied nutrients $(\mathrm{r}=0.97)$. Correlation of yield with nutrient uptake and nutrient uptake with applied nutrients were positive and significant (Table 4). Functional relationship between applied nutrient and fruit yield of Bt brinjal suggests that variation in yield can be attributed to the differences in applied nutrients. The result shows that higher nutrients gave higher fruit yield of Bt brinjal (Fig.1). Cost and return analysis of different treatments are presented in Table 5. Gross return (Tk. 587900/ha), gross margin (Tk. 417660/ha) and BCR (3.45) were found the highest in $\mathrm{T}_{3}$ treatment followed by $\mathrm{T}_{4}$ treatment and $\mathrm{T}_{2}$ treatment. The results indicated that higher nutrient dose gave higher economic advantage.

Table 4. Correlation of yield with nutrient uptake and nutrient uptake with applied nutrients (average of 2016-2017 and 2017-2018)

\begin{tabular}{c|c|c}
\hline Nutrient & $\begin{array}{c}\text { Correlation of yield with } \\
\text { nutrient uptake }(\mathrm{r})\end{array}$ & $\begin{array}{c}\text { Correlation of nutrient uptake } \\
\text { with applied nutrient }(\mathrm{r})\end{array}$ \\
\hline $\mathrm{N}$ & $0.98^{* *}$ & $0.86^{* *}$ \\
$\mathrm{P}$ & $0.95^{* *}$ & $0.73^{* *}$ \\
$\mathrm{~K}$ & $0.98^{* *}$ & $0.79^{* *}$ \\
$\mathrm{~S}$ & $0.89^{* *}$ & $0.85^{* *}$ \\
$\mathrm{Zn}$ & $0.99 * *$ & $0.91 * *$ \\
$\mathrm{~B}$ & $0.99 * *$ & $0.93^{* *}$ \\
$\mathrm{Ca}$ & $0.97^{* *}$ & $0.86^{* *}$ \\
\hline
\end{tabular}

** Significant at $1 \%$ level of probability

Table 5. Cost and return analysis of Bt brinjal as influenced by nutrient level (average of 2016-2017and 2017-2018)

\begin{tabular}{c|c|c|c|c}
\hline Treatment & $\begin{array}{c}\text { Gross return } \\
\text { (Tk./ha) }\end{array}$ & $\begin{array}{c}\text { Cost of cultivation } \\
\text { (Tk./ha) }\end{array}$ & $\begin{array}{c}\text { Gross margin } \\
\text { (Tk./ha) }\end{array}$ & BCR \\
\hline $\mathrm{T}_{1}$ & 223200 & 121600 & 101600 & 1.84 \\
$\mathrm{~T}_{2}$ & 420300 & 145920 & 274380 & 2.88 \\
$\mathrm{~T}_{3}$ & 587900 & 170240 & 417660 & 3.45 \\
$\mathrm{~T}_{4}$ & 468100 & 152000 & 316100 & 3.08 \\
$\mathrm{~T}_{5}$ & 333700 & 127680 & 206020 & 2.61 \\
\hline
\end{tabular}

Price $(\mathrm{Tk} . / \mathrm{kg})$

Urea:16.00, TSP:22.00, MOP:15.00, Gypsum:10.00, Zinc sulphate :170.00, Boric acid:200.00

Bt brinjal fruit: 9.50-10.00, Labour wage: Tk.400.00/day

$\mathrm{T}_{1}=120-36-90-15-2-1 \mathrm{~kg} / \mathrm{ha}$ N-P-K-S-Zn-B+ 3 t/ha poultry manure

$\mathrm{T}_{2}=150-45-112-18-2.5-1.25 \mathrm{~kg} / \mathrm{ha}$ N-P-K-S-Zn-B $+3 \mathrm{t} /$ ha poultry manure

$\mathrm{T}_{3}=180-54-135-22-3-1.50 \mathrm{~kg} / \mathrm{ha}$ N-P-K-S-Zn-B $+3 \mathrm{t} /$ ha poultry manure

$\mathrm{T}_{4}=150-45-112-18-2.5-1.25 \mathrm{~kg} / \mathrm{ha} \mathrm{N}-\mathrm{P}-\mathrm{K}-\mathrm{S}-\mathrm{Zn}-\mathrm{B}+6 \mathrm{t} / \mathrm{ha}$ poultry manure

$\mathrm{T}_{5}=120-36-90-15-2-1 \mathrm{~kg} / \mathrm{ha}$ N-P-K-S-Zn-B +6 t/ha poultry manure 


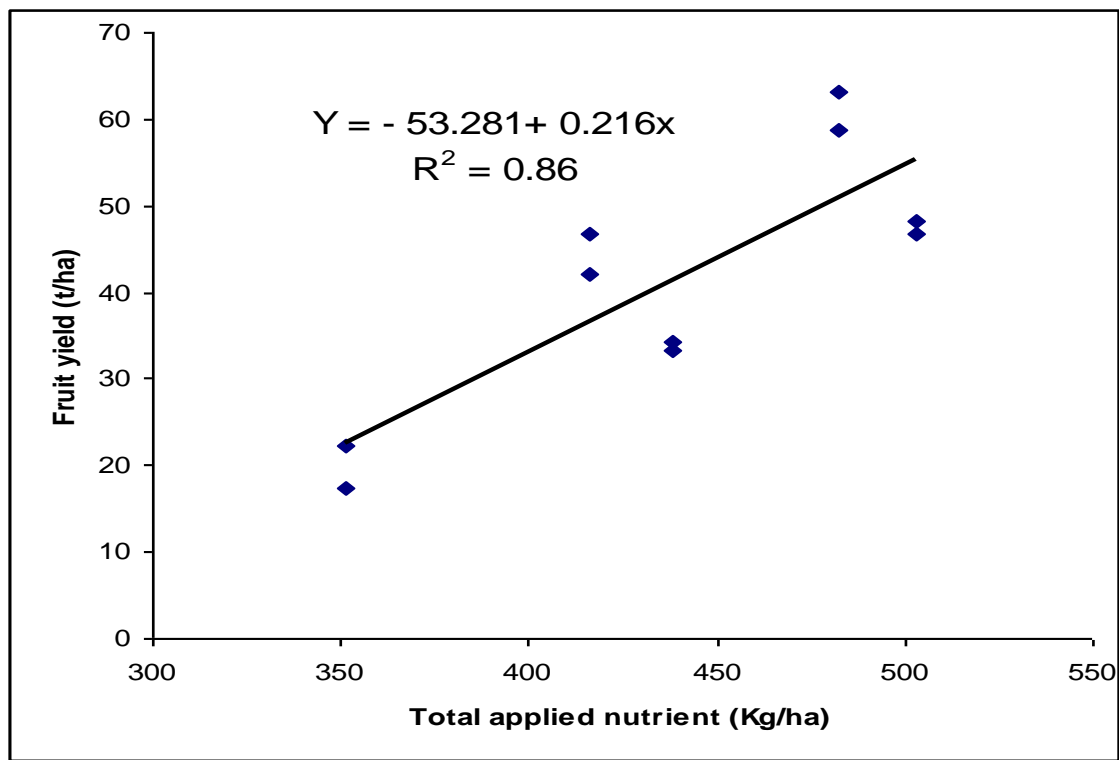

Fig. 1. Functional relationship between applied nutrient and fruit yield of Bt Brinjal (average of 2016- 2017 and 2017-2018).

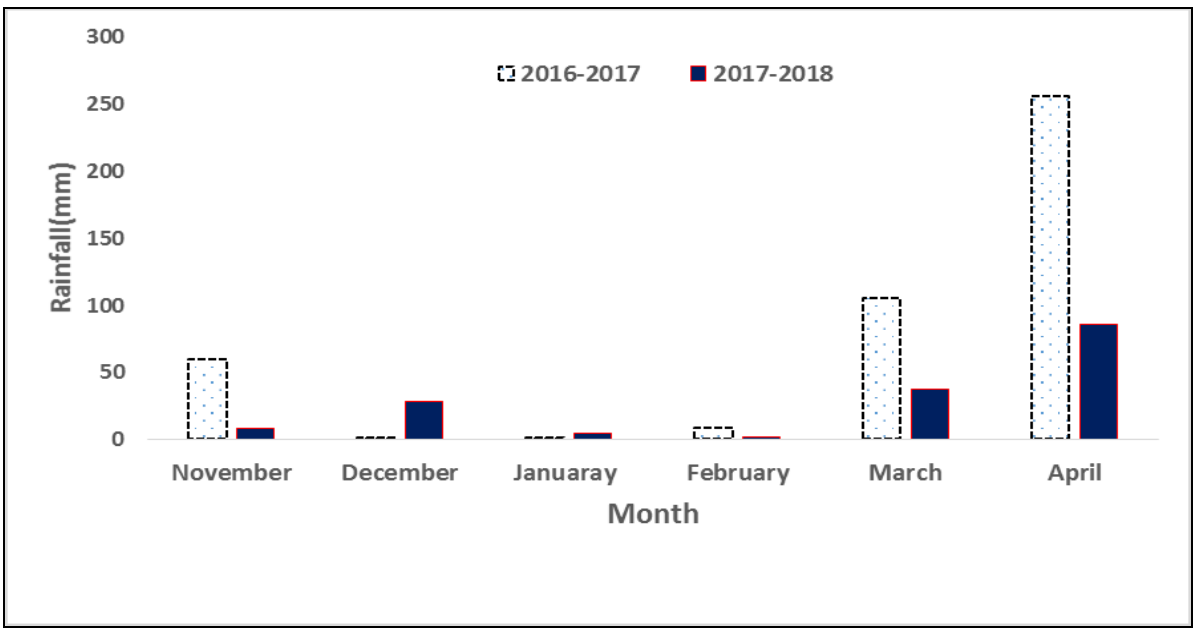

Fig.2. Rainfall distribution during growing period of Bt brinjal (2016-2017 and 2017-2018)

\section{Conclusion}

The results of two years' study revealed that application of 180-54-135-22-3$1.50 \mathrm{~kg} / \mathrm{ha} \mathrm{N}-\mathrm{P}-\mathrm{K}-\mathrm{S}-\mathrm{Zn}-\mathrm{B}$ along with $3 \mathrm{t} / \mathrm{ha}$ poultry manure was the suitable combination of nutrients for raising maximum fruit yield and also economically profitable for brinjal production in Chhiata series of the Grey Terrace soil of Gazipur. 


\section{References}

Armbust 2009: www.webpages.uidaho.edu/range357/notes/cover.pdf (Visited on 4 July 2018).

Ahmad, M., A. Asif, A. Amjad and S. Ahmadturk. 2011. J. Agric For. 35:641-648 (TÜBİTAKdoi:10.3906/tar-1005-995).

Anonymous.2017. Effect of different fertilizer treatment on eggplant production in Hainan. Intl. Plant nutrition (china.ipni.net/article/CNP-3119) (Visited 02.7.2017).

BARI (Bangladesh Argil. Res. Inst.). 2014. New technology of developing variety and production of Bt brinjal in Bangladesh (Bangladeshey Adunik Projuktir Bt beguner jat udvabhon o' utpadon projukti: In Bangla. BARI. Gazipur. 1701. pp.1-3.

BARI (Bangladesh Argil. Res. Inst.). 2017. On farm trial of BARI released Bt Brinjal varieties. In: Annual Res. Report (2016-2017). On Farm Res. Div. BARI. Gazipur. 1701. pp.505-510.

FRG (Fertilizer recommendation guide). 2012. BARC (Bangladesh Argil. Res. Council). Farm gate, Dhaka. 1215. pp.118-248.

FRG (Fertilizer recommendation guide). 2018. BARC (Bangladesh Argil. Res. Council). Farm gate, Dhaka. 1215. pp.102-103.

Gomez K.A. and A.A. Gomez. 1984. Statistical procedures for Agriculture Research. Intl. Rice Res. Inst. Philippines. pp. 87-411.

Ghosh, K., M. A. H. Chowdhury, M. H. Rahman and S. Bhattacherjee. 2014. Effect of integrated nutrient management on nutrient uptake and economics of fertilizer use in rice cv. NERICA 10. J. Bangladesh Agril. Univ., Mymensingh. 12(2): 273-277.

Khanum, M., M.M. Bazzaz and M.A.K. Mian. 2017. Effect of fertilizer management on fruit yield of Bt Brinjal at Dinajpur. In: Annual Res. Report (2016-2017). Agron. Div. BARI. Gazipur 1701. pp.36-37.

Masni Z. and M. E. Wasli. 2019. Yield performance and nutrient uptake of red rice variety (MRM 16) at different NPK fertilizer rates. Intl. J. Agron. p.6. (Malaysia). (https://doi.org/10.1155/2019/5134358) (Visited on 24 October 2019).

Mian, M.A.K. 2008. Performance of maize oriented cropping under different nutrient management. Ph.D. Dissertation. Department of Agronomy. Bangladesh Agril. Univ. Mymensingh. pp. 1-2.

Mian M.A.K. 2017. Development of production package and adaptation of Bt Brinjal in different agro-ecological zone as changing climate of Bangladesh. J. Sci. and Techno. Res., Ministry of Sci. and Techno. Bangladesh. pp.37-42.

Morgan, J. B. and Connolly, E. L. 2013. Plant-soil interactions: Nutrient uptake. Nature Education Knowledge. 4(8):2-5.

Sajid, M. and N. Amin. 2014. Effect of various combinations of nitrogen, phosphorus and potash on enhancing the flowering time in Chrysanthemum (Chrysanthemum morifolium). Int. J. Biosci. 4(10): 99-108.

Sharma, S.N and Guru, N C. 2016. Requirement of N P K for brinjal in silty loam soil at Haryana. Physiology J. 2(2): 321-324. (Visited 02.7.2017 physoc. online library. wiley. com/ hub/ journal /10.1111/(ISSN) 1469-7793/). 